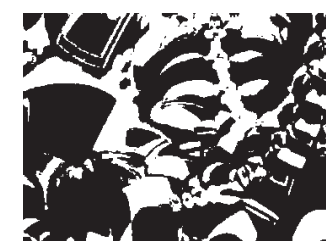

\title{
POLITICAL LEADERS \\ IN DAILY NEWSPAPERS: ANALYSIS OF THE 2016 CROATIAN PARLIAMENTARY ELECTIONS
}

Damir JUGO, Lana CIBOCl, Maja BANOVAC BARIĆ Edward Bernays University College, Zagreb

UDK: 070:32-051(497.5)"2016"
324(497.5):328"2016"

Izvorni znanstveni rad

Primlieno: 26. 7. 2017

This paper analyses the daily newspaper reporting on key political leaders of the 2016 parliamentary elections, the first early parliamentary elections in Croatia directly caused by a breakup of the ruling coalition. The introduction to these surprise and short-notice elections, at which preferential voting was practiced for only the second time, was a short election campaign and a change in leadership of the biggest party (HDZ), which triggered the extensive use of personalisation in campaigns run by the biggest parties and their coalitions. This study examines how five leaders of the most prominent political parties were presented in the six most relevant Croatian daily newspapers during the official election campaign. The findings reveal that the leaders of the two biggest parties dominated media coverage, but also that the only new leader, HDZ's Andrej Plenković, had a very favourable treatment in all of the analysed daily newspapers. Results also showed political programmes and private lives of the leaders to be marginal topics within the analysed leaders' media coverage.

Keywords: Croatia, 2016 parliamentary elections, political leaders, daily newspapers, personalisation 
The Croatian 2016 parliamentary elections were the second parliamentary elections in less than ten months. These first early elections in Croatian history ${ }^{1}$ were called after a split-up of the Croatian Democratic Union (HDZ) - MOST (Bridge of independent lists) coalition and a no-confidence vote to their technocrat prime minister Tihomir Orešković. After HDZ subsequently failed to form a new parliamentary majority, their president resigned and all political actors found themselves faced with the challenge of preparing their second election campaigns in less than a year. Several factors influenced this campaign; parties and coalitions preparing their second campaign in less than a year, HDZ as the biggest party entering the campaign with a newly elected leader and finally, use of the preferential voting system in Croatian parliamentary elections for only the second time.

It can be emphasised that all these factors encouraged the extensive use of party leaders as key communication elements in the campaigns their parties and coalitions had run for these elections. This political phenomenon, "personalisation", has been a widely researched topic among scholars. There is no doubt that the "core notion of personalisation is the fact that individual political actors become more prominent at the expense of parties and collective identities" (Karvonen, 2010, p. 4). Grbeša (2010, p. 58) notes that personalisation in parliamentary regimes signifies an important shift in the public focus from collective players (parties) to individuals (leaders) which, in terms of the media perspective, "in its broadest meaning refers to an increased media interest in candidates and party leaders and their rise to prominence within the party structures and election campaigns, which primarily evolved as a consequence of the demise of cleavage politics, the emergence of new technologies and media market expansion" (Grbeša, 2010, p. 58).

The use of personalisation throughout the campaign was evident. Besides emphasising personalisation as his own choice in HDZ's campaign, HDZ's new president and the later prime minister Andrej Plenković noted he himself encouraged all HDZ candidates to adopt the same approach. ${ }^{2}$ The identical approach was adopted by HDZ's main rival, the Social Democrat Party (SDP) and their "People's Coalition" that accentuated their leader Zoran Milanović as the central figure of their whole campaign (Vučković, 2016, p. 12). This came as a surprise considering his relatively low popularity as a former prime minister and the fact that his main opponent Plenković was a fresh face in national politics. Personalisation was undoubtedly omnipresent within this campaign; the brief analy- 
DRUŠ. ISTRAŽ. ZAGREB GOD. 27 (2018), BR. 3 STR. $473-491$

JUGO, D., $\mathrm{CIBOCl}$, L., BANOVAC BARIĆ, $M$. POLITICAL LEADERS.. using their leaders as focal points of their campaigns (Vučković, 2016, p. 15).

Motivated by the evident use of personalisation throughout the election campaign for the 2016 parliamentary elections, the objective of this paper is to examine how all daily newspapers with national outreach (Jutarnji list, Večernji list, 24 sata, Slobodna Dalmacija, Novi list and Glas Slavonije) reported on leaders of the five most relevant parties and coalitions during the official election campaign: Andrej Plenković (president of the right-wing Croatian Democratic Union, HDZ), Zoran Milanović (president of the Social Democratic Party, SDP), Božo Petrov (president of the Bridge of Independent Lists, MOST), Ivan Vilibor Sinčić (president of the Human Shield) and Milan Bandić (president of Bandić Milan 365 Party).

Using the content analysis method, all newspaper articles published in six Croatian daily newspapers mentioning one of the five leaders were analysed. This research sought to answer a total of four research questions to determine: (1) Was there any difference in the amount, type and tone of coverage devoted to the analysed leaders, (2) Whether HDZ's Andrej Plenković's "new face" advantage was reflected in the tone of his newspaper coverage, (3) What topics dominated the news reports about the analysed leaders and finally, (4) To what extent did the newspapers report on the political programmes and private lives of the leaders.

The study is divided into four parts. The second part provides a theoretical background on mediatisation and personalisation with a brief overview of previous research on personalisation in Croatian elections. The third part provides the context of the 2016 elections, while the fourth describes the methodology used and presents the key research findings. Finally, the fifth part of the paper is the conclusion of the study.

\section{LITERATURE REVIEW}

\section{Mediatisation and personalisation of politics}

Various authors (Swanson \& Mancini, 1996; Welsh, 1980; Strömbäck, 2008; Happer \& Philo, 2013) have emphasized that the majority of the public receives information about politics, election campaigns, as well as other social issues through the mass media. Strömbäck $(2008$, p. 230$)$ explains that changes brought on by the rising influence of the media during the last fifty years can be described with two concepts, mediation and mediatisation. When noting the difference between the two terms, he uses the work of Asp and Esaiasson (1996), Bennet and Entman (2001) and Nimmo and Combs (1983) to define mediat- 
DRUŠ. ISTRAŽ. ZAGREB GOD. 27 (2018), BR. 3, STR. 473-491

JUGO, D., CIBOCl, L., BANOVAC BARIĆ, $M$.: POLITICAL LEADERS.. ed politics as "a situation in which the media have become the most important source of information and vehicle of communication between the governors and the governed".

Along with the rising influence and the role of the media within the political sphere arose the phenomenon of personalisation in politics. Campus (2010, p. 221) explains this trend by emphasizing the limited capability of the media to transmit the complete picture of the political world and the consequent need to priorityse those aspects that can easily be transformed into media products, spectacular enough to attract large audiences.

Karvonen (2010, p. 4) defined personalisation as "the notion that individual political actors have become more prominent at the expense of parties and collective identities". Grbeša (2005, p. 54) notes the multilayer character of personalisation and states it can be viewed through three different dimensions; as a media phenomenon, a phenomenon of strategic communication of political parties and politicians and finally, through the phenomenon of personalised voting.

Downey and Stanyer (2010, p. 23) suggest there are two causal paths to personalisation: one where the make-up of political institutions is predominant causally and the character of media institutions is relatively unimportant; the other where a combination of political culture and media conditions explains personalisation irrespective of whether the political system is parliamentary or presidential. When discussing the media aspect of personalisation, Holtz-Bacha, Langer, and Merkle (2014, p. 153) note that authors such as Van Aelst, Sheafer and Stanyer (2012) use various terms like "individualisation" when describing the phenomenon of increased media visibility of candidates at the expense of their parties or the political organisations that they represent, or "presidentialisation" if media attention is directed specifically at leaders (Adam \& Maier, 2010; Langer, 2011; Vliegenhart, Boomgaarden, \& Boumans, 2011). "In the media, news frames set the parameters in which the audience discusses public events through 'persistent selection, emphasis and exclusion" (Gitlin, 1980, p. 7 as cited in Gan, Teo, \& Detenber, 2005, p. 442). Bittner (2011 as cited in Aaldering, van der Meer, \& van der Brug, 2018, p. 71) emphasise that media "play an important role in the way political leaders influence society" because voters "form their judgments about them mainly on the basis of their representation in the media" (e.g., Esser \& Strömbäck, 2014; Robinson, 1976; Strömbäck, 2008 as cited in Aaldering et al., 2018, p. 71), so the way they are presented in the media is highly important, especially the tone and the topic of the articles.

Holtz-Bacha et al. (2014) further note that, when discussing personalisation, one should not refer only to who the coverage focuses on, but also what it emphasises. These three 
DRUŠ. ISTRAŽ. ZAGREB GOD. 27 (2018), BR. 3 STR. $473-491$

JUGO, D., CIBOCl, L., BANOVAC BARIĆ, $M$. POLITICAL LEADERS.. authors explain that personalisation "goes beyond the visibility of individuals and refers to an increasing focus on their character or personalities" and, considering these aspects of possible approaches to personalisation, emphasise the need to be specific in two segments: the timeframe (elections and/or routine periods), and the location of personalisation manifestation (media coverage, party/candidate or government communication and/or voters' judgements) when analysing personalisation (Holtz-Bacha et al., 2014, p. 155). Therefore, this paper only focuses on "media personalisation" as defined by Holtz-Bacha et al. (2014, p. 155), i.e. on the analysis of party leaders' daily newspaper coverage through the 2016 election campaign.

\section{Personalisation in Croatian election campaigns}

Personalisation as a phenomenon in Croatian politics has been mainly researched by scholars analysing campaigns for both presidential (Brečić, Milanović, \& Šimunjak, 2012; Grbeša, 2005, 2012; Šimunjak, 2012; Šimunjak, Sinčić Ćorić, \& Brečić, 2017), and parliamentary elections (Kasapović, 2004; Grbeša, 2008, 2010; Vučković, 2010, 2016). From this research, various forms of media personalisation have emerged. From the aspect of this paper, particularly interesting are the studies of various parliamentary election campaigns. In her study of the 2003 elections, Kasapović (2004, p. 376) concluded that the personal image of the main candidates was mainly negative, but also that this image had generally no significant impact on voting preferences. She added the prediction that the main party leaders will primarily be perceived as party candidates and that their perception among the electorate will primarily be filtered through their party affiliation.

On the other hand, Grbeša (2008, p. 809) highlighted personalisation as a constant trend in parliamentary election campaigns in 2003 and 2007 while noting that "there is sufficient evidence to claim that the main purpose of election campaigns in Croatia is to promote the leader before the party". Grbeša also noted that Croatian politicians were generally not willing to expose their privacy for political purposes - straightforward references to leaders' private lives (family, personal feelings, hobbies etc.) were very rare $(2010$, p. 73). She further explains that examination of the media reports suggests that "the overall visibility of the leaders is increasing, which was consequently accompanied by the decreasing visibility of all other party officials". Grbeša (2010, p. 73) also adds that, although the growing visibility of the leaders may indicate that the newspaper coverage of elections has been increasingly personalised, analysis of the overall focus of the stories has revealed that the percentage of articles primarily concerned 
DRUŠ. ISTRAŽ. ZAGREB GOD. 27 (2018), BR. 3, STR. 473-491

JUGO, D., CIBOCI, L., BANOVAC BARIĆ, $M$.: POLITICAL LEADERS.. with the leaders' personal profiles was quite low with no significant increase between years. Also, in her research, Vučković $(2010$, p. 54) points to a relatively high percent of voters who changed their vote choice between these two elections, which could suggest the possibility that leaders, as a shortterm changeable variable, have had an important impact on voters' behaviour in Croatia.

All this research suggests that personalisation has been a constantly present phenomenon in Croatian election campaigns through the years, primarily in the form of individualisation as defined by Van Aelst et al. (2012) and, on the other hand, rarely in the form of privatisation (Grbeša, 2010, p. 74). Grbeša provides an argument for such behaviour; "it should be looked upon in the country's history, political and media culture, all heavily conditioned by the years of socialist regime in which the political was strictly divided from the private" (2010, p. 74). The latest research also confirms this trend; personalisation continues to be an integral part of parliamentary election campaigns in Croatia. In her analysis of the 2016 parliamentary elections, the same elections analysed in this research, Vučković (2016, p. 14) emphasised the aspect of personalisation and noted that the majority of the parties used their leaders as central figures of their campaigns.

\section{CONTEXT OF 2016 ELECTION CAMPAIGN}

As already mentioned, the 2016 Croatian parliamentary elections were specific from three perspectives: (1) the second elections in a ten-month period, (2) HDZ as the largest Croatian party entered the campaign with a new leader and finally (3) the preferential voting system in parliamentary elections was used for only the second time in history. Also, the HDZ - MOST government was a kind of novelty to Croatia since it was led by a non-partisan technocrat prime minister Tihomir Orešković, whose appointment as an independent "expert" was the key condition of MOST to form the Government with HDZ. Shortly after the Government was formed, relations between HDZ and MOST deteriorated, which led to mutual rejection of the other side's legislative proposals and appointments of various officials. Poor relations culminated when MOST and Orešković requested that HDZ president Tomislav Karamarko resigns from his deputy PM post in the Government over an alleged conflict of interest. He resigned, but at the same time HDZ initiated a no confidence vote for the PM, which passed successfully thanks to the support of the opposition. After a subsequent attempt by HDZ to form a new parliamentary majority ended in failure, Karamarko resigned from the post of HDZ president, while the Parliament voted to dissolve itself on 20 June, making it possible for new elections to be called for 11 September. 
DRUŠ. ISTRAŽ. ZAGREB GOD. 27 (2018), BR. 3 STR. $473-491$

JUGO, D., $\mathrm{CIBOCl}$, L., BANOVAC BARIĆ, $M$. POLITICAL LEADERS..
The campaign for the HDZ president followed immediately with Andrej Plenković, then member of the European Parliament, announcing his candidacy and shortly after becoming the only candidate. Plenković wisely insisted on a full intraparty campaign until elected party president on 17 July, which resulted in significant media attention for him personally as a new leader and marked the start of an early election campaign. Having a completely different public profile than his predecessor as well as the advantage of being a new face; smooth, moderate and measured, Plenković insisted on a personalised campaign for him personally and for all HDZ MP candidates (Dnevnik.hr, 2016), which somewhat imposed the personalised approach on other parties and their leaders. Having entered the campaign as trailers to the leading SDP according to publicly presented surveys, ${ }^{3}$ personalising the campaign was a logical choice for HDZ and their partners for whom their new leader was the main advantage, but it was surprising to see SDP and their People's Coalition accept this challenge and use the same approach, since their leader Milanović, former prime minister, was highly unpopular according to the CRO Demoskop public survey. ${ }_{4}$ Personalisation also dominated other parties' campaigns. Petrov, the leader of MOST, was also in the focus of his party's campaign that directly attacked both HDZ and SDP, with the aim of positioning themselves as a legitimate alternative to the two "big" parties. The fourth profiled leader, Sinčić, is the president of "Human Shield", the party formed from an anti-eviction NGO. The final high-profile leader in these elections was the long-time mayor of Croatia's capital city of Zagreb, Milan Bandić, whose party actually bears his own name - "Bandić Milan 365 Labour and Solidarity Party".

The elections held on 11 September had a turnout of only 52 percent. HDZ became the relative winner with 61 seats, SDP's People's Coalition followed with 54, while MOST was placed third having won 13 seats. Human Shield won a surprising 8 seats while Bandić and his party won only 2 . The rest of the overall number of 156 seats was divided among eight national minority MPs, two regional parties and one independent candidate from the Croatian diaspora.

\section{RESEARCH DESIGN}

This paper uses content analysis, the frequently used method of analysing political communication, to analyse how daily newspapers reported on the five most prominent political leaders of the 2016 election, during the official election campaign period. Benoit (2011, p. 268) emphasises the importance of this method for political communication and notes that, besides other available qualitative and critical methods for 
DRUŠ. ISTRAŽ. ZAGREB GOD. 27 (2018), BR. 3, STR. 473-491

JUGO, D., CIBOCI, L., BANOVAC BARIĆ, M.: POLITICAL LEADERS.. understanding texts, content analysis remains a relevant means of measuring or quantifying the dimensions of the content of messages. This research attempts to determine the manner in which six daily newspapers with national reach (Jutarnji list, Večernji list, 24 sata, Novi list, Slobodna Dalmacija and Glas Slavonije) reported on five key political leaders (Plenković, Milanović, Petrov, Sinčić and Bandić) during the official election campaign lasting from 16 August to 9 September 2016. The research sought to answer four research questions:

RQ1: Was there any difference in the amount, type and tone of coverage devoted to the analysed leaders?

RQ2: Is there evidence to suggest that HDZ's Andrej Plenkovićs "new face" advantage was reflected in the tone of his newspaper coverage?

RQ3: What topics dominated the daily newspaper reports about the analysed leaders?

RQ4: To what extent did the newspapers report on the political programmes and private lives of the leaders?

Based on the research questions, an analytical matrix was formed which consisted of three key parts. The first set of questions tended to examine the amount of attention devoted to each political leader, primarily through the amount and the type of published articles. Namely, analytical articles point to a more detailed approach, providing more information to the reader to form their own opinion. This set of questions analysed the tone of the articles, with the primary aim of determining the light in which all of the leaders were reported on, and which enabled the comparison among themselves. Positive articles were considered to highlight the successes and praises, while negative articles included all those articles in which there were criticisms or accusations of a certain leader of any kind. The second set analysed the articles to determine the content: the extent to which the newspapers reported on different topics connected to the elections. This question consisted of the following variables: election campaign, public accusations among leaders themselves, political rallies, possible post-election coalitions, political programmes, the relationship of Croatia with neighbouring countries, ridiculing the leaders of other political parties, private lives, internal party conflicts, glorifying the leader's party and other (mentioning leaders in a context not related to the campaign). The third set of questions analysed the articles to determine the extent to which the newspapers reported on political programmes and private lives (privatisation) of the leaders.

The unit of analysis was the newspaper article. ${ }^{5}$ All articles mentioning the name of five leaders (Andrej Plenković, 
DRUŠ. ISTRAŽ. ZAGREB GOD. 27 (2018), BR. 3 STR. $473-491$

JUGO, D., $\mathrm{CIBOCl}$, L., BANOVAC BARIĆ, $M$. POLITICAL LEADERS..
Zoran Milanović, Božo Petrov, Milan Bandić, Ivan Vilibor Sinčić) were analysed. Articles mentioning only political parties but not their leaders, were excluded from the analysis. A total of 903 newspaper articles were analysed - 233 articles in Novi list, 211 articles in Jutarnji list, 173 articles in Večernji list, 154 articles in Slobodna Dalmacija, 77 articles in 24 sata and 55 articles in Glas Slavonije. Using Holsti's formula, intercoder reliability was checked. The reliability coefficient was 0.9 .

\section{RESULTS AND DISCUSSION}

In order to present the research findings in a more distinct manner, this chapter is organised in accordance with the research questions posed.

RQ1: Was there any difference in the amount, type and tone of coverage devoted to the analysed leaders?

RQ2: Is there evidence to suggest that HDZ's Andrej Plenkovićs "new face" advantage was reflected in the tone of his newspaper coverage?

Even a first look at the results of the distribution of articles shows a dominant position of the leaders of the two largest parties; more than a half of the analysed articles (55.8\%) reported on Milanović (SDP) and Plenković (HDZ). Also, 16.6\% of articles reported on more than one leader, while the rest is divided among Petrov (13.1\%) and Bandić $(11.1 \%)$. The leader with the least newspaper coverage was Sinčić, whose coverage amounts to only $3.4 \%$ of articles. Detailed results according to newspaper are presented in Table 1 . The detected focus on leaders of the two largest parties was more than evident and at the same time indicates a clearly unbalanced focus of the media between "bigger" and "smaller" political parties, which

(1) TABLE 1

Political party leaders at the centre of the article in the analysed newspapers $(\mathrm{N}=903)$ raises the question of the latter being deprived of the equal chance to present their programme and ideas, especially considering balanced, impartial and fair reporting as one of the key principles of media reporting (Malović, 2006).

\begin{tabular}{|c|c|c|c|c|c|c|c|c|c|c|c|}
\hline & \multicolumn{2}{|c|}{ Večernji list } & \multicolumn{2}{|c|}{ Jutarnji list } & 24 sata & \multicolumn{2}{|c|}{ Novi list } & \multicolumn{2}{|c|}{ Slobodna Dalmacija } & \multicolumn{2}{|c|}{ Glas Slavonije } \\
\hline & $\mathrm{N}$ & $\%$ & $\mathrm{~N}$ & $\%$ & $\mathrm{~N} \%$ & $\mathrm{~N}$ & $\%$ & $\mathrm{~N}$ & $\%$ & $\mathrm{~N}$ & $\%$ \\
\hline Andrej Plenković & 31 & 17.9 & 46 & 21.8 & 1823.4 & 74 & 31.8 & 37 & 24 & 13 & 23.6 \\
\hline Zoran Milanović & 63 & 36.4 & 60 & 28.4 & 1924.7 & 78 & 33.5 & 47 & 30.5 & 17 & 30.9 \\
\hline Božo Petrov & 16 & 9.2 & 27 & 12.8 & 1316.9 & 30 & 12.9 & 22 & 14.3 & 10 & 18.2 \\
\hline Ivan Vilibor Sinčić & 7 & 4.0 & 4 & 1.9 & 22.6 & 11 & 4.7 & 5 & 3.2 & 2 & 3.6 \\
\hline Milan Bandić & 22 & 12.7 & 35 & 16.6 & 1013.0 & 14 & 6.0 & 16 & 10.4 & 3 & 5.5 \\
\hline $\begin{array}{l}\text { More than one } \\
\text { political leader }\end{array}$ & 34 & 19.8 & 39 & 18.5 & 1519.4 & 26 & 11.1 & 27 & 17.6 & 10 & 18.2 \\
\hline Total & 173 & 100 & 211 & 100 & 77100 & 233 & 100 & 154 & 100 & 55 & 100 \\
\hline
\end{tabular}


DRUŠ. ISTRAŽ. ZAGREB GOD. 27 (2018), BR. 3, STR. $473-491$

JUGO, D., CIBOCl, L., BANOVAC BARIĆ, $M$ : POLITICAL LEADERS.

(1) TABLE 2

Type of journalistic article devoted to the political leaders $(\mathrm{N}=903)$
Apart from the number of articles, it is important to analyse the type of journalistic articles as well. Namely, more extensive journalistic types such as reportages, analysis articles and comments point to a more detailed, and often an approach of greater quality to the subject itself, giving more information to the reader to form their own opinion. The comparative analysis of the article types suggests that the "traditional" forms of election reporting such as classical news (17.2\%) and reports $(31.7 \%)$ prevailed among the press coverage of party leaders. The rest of the articles are analysis articles (16.4\%), comments $(17.3 \%)$, interviews $(9.5 \%)$, reportages $(2 \%)$, readers' letters $(2.4 \%)$ and $3.5 \%$ of other content (photo news, denial, etc.). Detailed results in relation to the political leaders are presented in Table 2. It can be noted that Milanović was more often the topic of various comments (more than double compared to the number of comments devoted to Plenković), which suggests much more analytical approach to his actions during the campaign. An increased amount of analytical approach (the percentage of comments) was also noticed in the newspaper coverage devoted to Petrov (17.8\%). That the interest of daily newspapers for Sinčić and Bandić during the campaign was very small, in addition to the number of articles, is reflected in the fact that most of these articles were published in the form of the simplest and shortest of newspaper types - news and reports.

\begin{tabular}{|c|c|c|c|c|c|c|c|c|c|c|c|c|}
\hline & Andrej Ple & nković & Zoran N & Milanović & Božo & Petrov & $\begin{array}{r}\text { Iv } \\
\text { Vilibo }\end{array}$ & $\begin{array}{l}\text { ran } \\
\text { r Sinčić }\end{array}$ & Milan & Bandić & $\begin{array}{l}\text { More th } \\
\text { political }\end{array}$ & $\begin{array}{l}\text { tan one } \\
1 \text { leader }\end{array}$ \\
\hline & $\mathrm{N}$ & $\%$ & $\mathrm{~N}$ & $\%$ & $\mathrm{~N}$ & $\%$ & $\mathrm{~N}$ & $\%$ & $\mathrm{~N}$ & $\%$ & $\mathrm{~N}$ & $\%$ \\
\hline News & 39 & 17.9 & 43 & 15.2 & 18 & 15.3 & 9 & 29.0 & 32 & 32.0 & 14 & 9.3 \\
\hline Reports & 80 & 36.5 & 88 & 31 & 47 & 39.8 & 11 & 35.5 & 38 & 38.0 & 22 & 14.6 \\
\hline Analysis articles & 34 & 15.5 & 43 & 14.3 & 15 & 12.7 & 4 & 12.9 & 8 & 8.0 & 44 & 29.1 \\
\hline So-called "sivac" & 6 & 2.7 & 12 & 4.3 & 0 & 0.0 & 1 & 3.2 & 0 & 0.0 & 1 & 0.7 \\
\hline Reportages & 8 & 3.7 & 0 & 0.0 & 1 & 0.8 & 0 & 0.0 & 0 & 0.0 & 9 & 6.0 \\
\hline Readers' letters & 6 & 2.7 & 6 & 2.2 & 7 & 5.9 & 0 & 0.0 & 0 & 0.0 & 3 & 2.0 \\
\hline Comments & 21 & 9.6 & 62 & 21.9 & 21 & 17.8 & 2 & 6.5 & 11 & 11.0 & 39 & 25.8 \\
\hline Interviews & 22 & 10.0 & 26 & 9.3 & 8 & 6.8 & 4 & 12.9 & 10 & 10.0 & 16 & 10.5 \\
\hline Photo news & 2 & 0.9 & 2 & 0.8 & 0 & 0.0 & 0 & 0.0 & 1 & 1.0 & 0 & 0.0 \\
\hline Denials & 1 & 0.5 & 1 & 0.5 & 1 & 0.9 & 0 & 0.0 & 0 & 0.0 & 0 & 0.0 \\
\hline Other & 0 & 0.0 & 1 & 0.5 & 0 & 0.0 & 0 & 0.0 & 0 & 0.0 & 3 & 2.0 \\
\hline Total & 219 & 100 & 284 & 100 & 118 & 100 & 31 & 100 & 100 & 100 & 151 & 100 \\
\hline
\end{tabular}

Although the analysed newspapers gave the largest amount of attention to the leaders of the largest political parties, the way they presented them was completely different (see Table 3). Namely, the tone of media coverage is extremely important because it may potentially have an influence on the voters (Gerber, Karlan, Bergan, 2009; Hopmann, Vliegenthart, 
DRUŠ. ISTRAŽ. ZAGREB GOD. 27 (2018), BR. 3 STR. $473-491$

JUGO, D., $\mathrm{CIBOCl}$, L., BANOVAC BARIĆ, $M$. POLITICAL LEADERS...

(1) TABLE 3

The portrayal of political leaders $(\mathrm{N}=903)$
De Vreese, Albæk, 2010; Dobrzynska, Blais, \& Nadeau, 2002). The results showed that Milanović had been shown in a much more negative manner in comparison to Plenković. The analysis showed Milanović being portrayed negatively ${ }^{6}$ in a surprisingly high percentage of $47.5 \%$ articles, while being presented positively in only $13 \%$. On the other hand, his main rival for the prime ministerial post, Plenković had much more favourable media coverage, being presented positively in $25.6 \%$ of articles and only $16.9 \%$ in a negative way (see Table 3). Sinčić (29\%) and Bandić (27\%) were the leaders with the most positive articles, while again Sinčić had the least of negative articles published about himself (3.2\%). Sinčićs positive presentation in the media was particularly influenced by the fact that he most often presented his programme in the media and did not engage in mutual conflicts between political leaders. On the other hand, journalists were very critical about Milanović, especially in comments, because of his interferences in the private lives of his opponents. The high percentage of negative articles on Petrov was as well the result of a number of published comments in which journalists expressed their opinions and criticisms on his work and ideas. It is also interesting to note that the two leaders who were most commonly the topic of newspaper comments (Milanović and Petrov, Table 2) had the highest negative ratio of all leaders (Table 3).

\begin{tabular}{|c|c|c|c|c|c|c|c|c|c|c|c|}
\hline \multirow[t]{2}{*}{ Andre } & \multicolumn{2}{|c|}{ ej Plenković } & \multicolumn{2}{|c|}{ Zoran Milanović } & \multicolumn{2}{|c|}{ Božo Petrov } & \multicolumn{2}{|c|}{$\begin{array}{c}\text { Ivan } \\
\text { Vilibor Sinčić }\end{array}$} & \multicolumn{2}{|c|}{ Milan Bandić } & $\begin{array}{l}\text { More than one } \\
\text { political leader }\end{array}$ \\
\hline & $\mathrm{N}$ & $\%$ & $\mathrm{~N}$ & $\%$ & $\mathrm{~N}$ & $\%$ & $\mathrm{~N}$ & $\%$ & $\mathrm{~N}$ & $\%$ & $\mathrm{~N} \quad \%$ \\
\hline Positive manner & 56 & 25.6 & 37 & 13.0 & 14 & 11.9 & 9 & 29.0 & 27 & 27.0 & 74.6 \\
\hline Negative manner & 37 & 16.9 & 135 & 47.5 & 39 & 33.1 & 1 & 3.2 & 31 & 31.0 & 2717.9 \\
\hline Neutral manner & 118 & 53.8 & 94 & 33.2 & 57 & 48.2 & 19 & 61.3 & 38 & 38.0 & 9462.3 \\
\hline $\begin{array}{l}\text { Difficult to } \\
\text { determine }\end{array}$ & 8 & 3.7 & 18 & 6.3 & 8 & 6.8 & 2 & 6.5 & 4 & 4.0 & 2315.2 \\
\hline Total & 219 & 100 & 284 & 100 & 118 & 100 & 31 & 100 & 100 & 100 & 151100 \\
\hline
\end{tabular}

One of the research questions tended to determine whether the fact that Plenković was the only fresh face among the analysed leaders had any influence on the newspaper coverage. The research clearly showed that Plenković attracted a lot of media attention during the election campaign, but unlike his rivals, especially SDP leader Zoran Milanović, who were mainly portrayed in a negative manner, his coverage had a positive ratio ( $25.6 \%$ positive and $16.9 \%$ negative articles). Plenković was actually the only of the analysed leaders with a positive coverage ratio except Sinčić, leader of the populist 
DRUŠ. ISTRAŽ. ZAGREB GOD. 27 (2018), BR. 3, STR. 473-491

JUGO, D., CIBOCl, L., BANOVAC BARIĆ, $M$.: POLITICAL LEADERS..
Human Shield party who, on the other hand, was the main topic of significantly less newspaper coverage (31 articles) than Plenković himself (219 articles). Although it would be pretentious to claim that Plenković's favourable coverage was a direct consequence of the fact that he was a fresh face in these elections, the fact that he was leading the largest Croatian party that actually caused these early elections and had significantly more positive coverage than his rivals, especially his main rival Zoran Milanović, who was heavily criticised and negatively reported on by the print media, suggests the existence of a certain amount of advantage caused by the fact that he was a newly elected leader, less than a couple of months before these elections.

RQ3: What topics dominated the daily newspaper reports about the analysed leaders?

RQ4: To what extent did the newspapers report on the political programmes and private lives of the leaders?

For the research it was crucial to analyse which topics dominated the pre-election campaign in articles where leaders were the focus of attention. It is important whether a politician is placed in the context of an election campaign and programmes of a political party or in the context of internal party conflicts or the ridiculing of political opponents. All this contributes to creating the public picture of a politician and is, therefore, important in the segment of media personalisation of the mentioned leaders. This research showed that the most common topic of the analysed articles $(43.5 \%)$ was the election campaign itself which included candidates' various daily activities. There were no major differences in the representation of most topics among the analysed leaders. The biggest difference was recorded on the topic of public accusations among the leaders themselves. The analysis showed Milanović leading a clearly negative campaign directed towards Plenković and HDZ; twice as many articles were published about Milanović criticising Plenković than the other way around. Other topics are listed in Table 4.

As stated earlier, media coverage of elections in Croatia in the last two decades was strongly personalised (Kasapović, 2004; Grbeša, 2008, 2010) with the emphasis on the professional, and not the private life of politicians. This research confirmed this trend once more; only 5.3\% of all analysed articles had as their topic a certain aspect of private lives ${ }^{7}$ of the analysed leaders which clearly shows that the prevailing form of personalisation was individualisation as defined by Van Aelst et al. (2012), and not privatisation. Detailed results are present- 
ed in Table 5. The results did not show any difference among the political party leaders, but it is interesting to point out that none such article had been published about Sinčić.

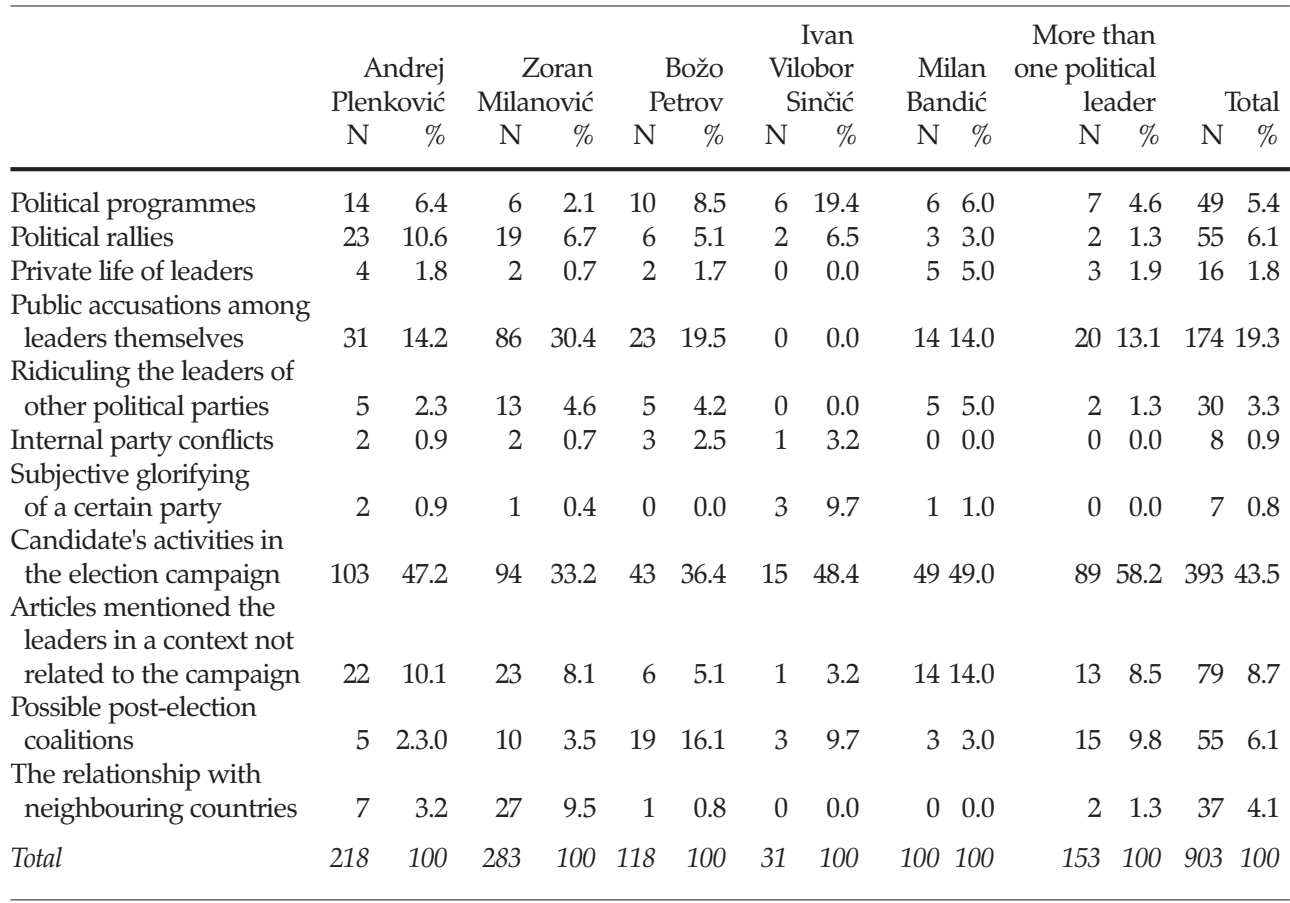

Ivan More than one Andrej Plenković Zoran Milanović Božo Petrov Vilibor Sinčić Milan Bandić political leader

\begin{tabular}{lrrrrrrrrrrrr} 
& $\mathrm{N}$ & $\%$ & $\mathrm{~N}$ & $\%$ & $\mathrm{~N}$ & $\%$ & $\mathrm{~N}$ & $\%$ & $\mathrm{~N}$ & $\%$ & $\mathrm{~N}$ & $\%$ \\
\hline Yes & 6 & 2.7 & 9 & 3.2 & 2 & 1.7 & 0 & 0 & 5 & 5 & & 8 \\
No & 213 & 97.3 & 275 & 96.8 & 116 & 98.3 & 31 & 100 & 95 & 95 & 143 & 94.7 \\
Total & 219 & 100 & 284 & 100 & 118 & 100 & 31 & 100 & 100 & 100 & 151 & 100 \\
\hline
\end{tabular}

(1) TABLE 4

The main topic of articles $(\mathrm{N}=903)$

(1) TABLE 5

The private life issues of political party leaders ( $N=903$ )
This study also analysed the number of articles that discussed leaders and their party programmes. Namely, it was important to research how many party political programmes were presented through the political party leaders themselves. Only $13.4 \%$ of the articles about these leaders had as their topic political programmes. While no article was published about his private life, it is interesting to see that Sinčić spoke the most about his political programme; in a total of $45.2 \%$ of articles where he was the main topic. On the other hand, Milanović did the same in only $4.6 \%$ of articles (see Table 6), which once more suggests the negative aspect of his campaign. It is interesting to note that Sinčić, as the leader who talked about his party's programme more than any other leader, had much 
(1) TABLE 6

Presentation of programmes and ideas of political parties through the party leader $(\mathrm{N}=903)$ more favourable media coverage in terms of tone, recording the most positive and neutral articles, and the least negative ones. On the other hand, it is also worth noticing that Milanović, who had the most negative coverage, talked least about the programme and ideas of his party.

\begin{tabular}{|c|c|c|c|c|c|c|c|c|c|c|c|}
\hline & \multicolumn{2}{|c|}{ Andrej Plenković } & \multicolumn{2}{|c|}{ Zoran Milanović } & \multicolumn{2}{|c|}{ Božo Petrov } & \multicolumn{2}{|c|}{$\begin{array}{c}\text { Ivan } \\
\text { Vilibor Sinčić }\end{array}$} & \multicolumn{2}{|c|}{ Milan Bandić } & $\begin{array}{l}\text { More than one } \\
\text { political leader }\end{array}$ \\
\hline & $\mathrm{N}$ & $\%$ & $\mathrm{~N}$ & $\%$ & $\mathrm{~N}$ & $\%$ & $\mathrm{~N}$ & $\%$ & $\mathrm{~N}$ & $\%$ & $\mathrm{~N} \quad \%$ \\
\hline Yes & 46 & 21 & 13 & 4.6 & 27 & 22.9 & 14 & 45.2 & 16 & 16 & $5 \quad 3.3$ \\
\hline No & 173 & 79 & 271 & 95.4 & 91 & 77.1 & 17 & 54.8 & 84 & 84 & 14696.7 \\
\hline Total & 219 & 100 & 284 & 100 & 118 & 100 & 31 & 100 & 100 & 100 & 100 \\
\hline
\end{tabular}

\section{CONCLUSION}

The battle for positive media coverage was clearly the main challenge of all analysed political leaders during this campaign, especially following the very well-known supremacy of the media as the most important source of information for potential voters and the fact that the campaign for these elections was clearly a surprise to all major parties and coalitions. The research conducted for the purpose of this paper clearly showed the dominance of the largest parties (HDZ and SDP) in the newspaper coverage of the election campaign. Both party presidents, Plenković and Milanović, achieved the prevailing majority of all newspaper coverage, which consequently seriously reduced media space for all other politicians and parties. The analysed newspapers presented all political leaders much more in a negative than a positive light throughout the election campaign. While both of them led highly personalised campaigns, Plenković, clearly using his advantage as a fresh face, achieved much more positive coverage than Milanović, who on the other hand achieved the largest frequency of coverage, but unfortunately for him, in a primarily negative manner. This can be described as a clear consequence of his approach to the media, where he clearly led a negative campaign directed towards Plenković; an approach that clearly showed to be without any success. It is also interesting to note that the politician with the most favourable newspaper coverage was at the same time the biggest underdog of the elections, Sinčić. A total of $29 \%$ of articles published about Sinčić were positive, while only $3.2 \%$ were negative. Besides Sinčić, Plenković was the only politician with a positive media coverage ratio, which suggests that his attribute of being the only fresh face of these elections had a certain influence on the tone of the newspaper coverage about him and his actions during the campaign. This research suggests that, among the 
DRUŠ. ISTRAŽ. ZAGREB GOD. 27 (2018), BR. 3 STR. 473-491

JUGO, D., CIBOCl, L., BANOVAC BARIĆ, $M$. POLITICAL LEADERS.. analysed media coverage devoted to leaders of the major political parties, individualisation was the prevailing type of personalisation in the Croatian election campaigns and also showed private lives to be a marginal topic within the campaign; only 5.3\% of all articles had private lives as their main topic. On the other hand, political programmes also proved to be a very rare topic of the analysed coverage. Only every eighth article about political leaders focused on their programmes. However, an interesting finding of this research could be the fact that Sinčić, who heavily insisted on his and his party's programme (45.2\% of his coverage was focused on his programme), achieved the most positive coverage and his party a surprising election result. Regular daily activities of the analysed leaders mostly dominated the coverage with mutual criticism of the leaders being practically the only topic standing out, which suggests that it is hard to point out certain elements that stand out from the coverage of this campaign.

Finally, the media - through their reporting, clearly determined how certain leaders and the topics connected to them were presented to the public, and in this manner could influence the election behaviour of voters. To completely understand the implications of the media coverage on the results of the elections, further research is needed. Further studies should focus on analysing other types of media (TV, radio, news portals), which could provide a more complete picture of the Croatian media coverage on election campaigns with the emphasis on political leaders.

\section{NOTES}

1 The first and only previous early elections in Croatia took place in 1995 after the then Croatian president and president of HDZ Franjo Tuđman, despite having a comfortable majority, dissolved the parliament and called for early elections, with the premise of using national euphoria and his party's popularity after the Homeland War military action "Storm" that recovered most of the occupied Croatian territory.

2 In a TV interview for Nova TV on 25 October 2016, Plenković noted that "HDZ and I led a personalised campaign on a national level and I personally encouraged our candidates on the constituency level to run their own personalised campaigns" (Dnevnik.hr, 2016).

${ }^{3}$ According to the CRO Demoskop monthly survey in July 2016 conducted by the "Promocija Plus" agency, SDP entered the campaign with the support of 31.8 percent, HDZ followed with 22.7 percent, Most was the third party with 9.8 percent while Human Shield was the fourth option with 5.3 percent.

4 The CRO Demoskop monthly survey for July 2016 identified SDP and People's Coalition leader Milanović as the second most unpop- 
DRUŠ. ISTRAŽ. ZAGREB GOD. 27 (2018), BR. 3, STR. 473-491

JUGO, D., CIBOCI, L., BANOVAC BARIĆ, $M$.: POLITICAL LEADERS.. ular Croatian politician with 19.7 percent of the respondents indicating him as a "the most negative politician in Croatia".

5 The term "newspaper article" implies all articles in daily newspapers (news, feature, photo news, commentaries, columns, reviews etc.), except advertisements." (Ciboci, 2014, p. 98).

${ }^{6}$ The subjectivity of researchers must be taken into consideration when analysing this category.

7 Personal and family life was considered a threath to privacy (Media Act, NN 59/04, 84/11, 81/13).

Asp, K., \& Esaiasson, P. (1996). The modernization of Swedish campaigns: Individualization, professionalization and medialization. In D. Swanson \& P. Mancini (Eds.), Politics, media and modern democracy (pp. 73-91). Westport: Praeger.

Aaldering, L., van der Meer, T., \& van der Brug, W. (2018). Mediated leader effects: The impact of newspapers' portrayal of party leadership on electoral support. The International Journal of Press/Politics, 23(1), 70-94. https://doi.org/10.1177/1940161217740696

Adam, S., \& Maier, M. (2010). Personalisation of politics. A critical review and agenda for research. Annals of the International Communication Association, 34(1), 213-257. https://doi.org/10.1080/23808985.2010. 11679101

Bennet, L., \& Entman. R. (2001). Mediated politics. Cambridge, UK: Cambridge University Press.

Benoit, W. L. (2011). Content analysis in political communication. In E. P. Bucy, \& R. L. Holbert (Eds.), Sourcebook for political communication research (pp. 268-283). New York: Routledge. https://doi.org/10.4324/ 9781315782713

Brečić, K., Milanović, L., \& Šimunjak, M. (2012). "Amerikanizacija" bez trivijalizacije: Analiza novinskog izvještavanja o predizbornoj kampanji Vesne Pusić 2009. godine ["Americanization" without trivialization: Analysis of newspaper reporting about Vesna Pusić's 2009 presidential campaign]. Društvena istraživanja, 21(2), 523-544. https://doi. org/10.5559/di.21.2.12

Campus, D. (2010). Mediatization and personalization of politics in Italy and France: The cases of Berlusconi and Sarkozy. International Journal of Press/Politics, 15(2), 219-235. https://doi.org/10.1177/1940161 209358762

Ciboci, L. (2014). Zaštita privatnosti djece u Večernjem listu i Jutarnjem listu u 2013. godini u odnosu na 2010. godinu [The protection of children's privacy in Večernji List and Jutarnji List 2010-2013: A comparative analysis]. Medijske studije, 5(9), 92-106.

Dnevnik.hr (10 September 2016). Gotovo milijun gledatelja gledalo debatu na Novoj TV. Available at http://dnevnik.hr/vijesti/hrvatska/gotovomilijun-gledatelja-gledalo-debatu-na-novoj-tv---367913.html.

Dobrzyinska, A., Blais, A., \& Nadeau, R. (2002). Do the media have a direct impact on the vote? The case of the 1997 Canadian elections. 
DRUŠ. ISTRAŽ. ZAGREB GOD. 27 (2018), BR. 3 STR. 473-491

JUGO, D., CIBOCl, L., BANOVAC BARIĆ, $M$. POLITICAL LEADERS..
International Journal of Public Opinion Research, 15(1), 27-43. https://doi. org/10.1093/ijpor/15.1.27

Downey, J., \& Stanyer, J. (2010). Comparative media analysis: Why some fuzzy thinking might help. Applying fuzzy set qualitative comparative analysis to the personalisation of mediated political communication. European Journal of Communication, 25(4), 331-347.

Esser, F., \& Strömbäck, J. (2014). Mediatization of politics: Transforming democracies and reshaping politics. In K. Lundby (Ed.), Mediatization of communication (pp. 375-403). Berlin: De Gruyter Mounton, https://doi.org/10.1515/9783110272215.375.

Gan, F., Teo, J. T., \& Detenber, B. H. (2005). Framing the battle for the White House. A comparison of two national newspapers' coverage of the 2000 United States Presidential Election. Gazette: The International Journal for Communication Studies, 67(5), 441-467. https://doi. org/10.1177/0016549205056052

Gerber, A. S., Karlan, D., \& Bergan, D. (2009). Does the media matter? A field experiment measuring the effect of newspapers on voting behavior and political opinions. American Economic Journal: Applied Economics, 1(2), 35-52. https://doi.org/10.1257/app.1.2.35

Grbeša, M. (2005). Personalization in Croatian Presidential Election in 2000: How personal did the candidates go and what did the press cover? Politička misao, 41(5), 52-73.

Grbeša, M. (2008). Politika osebnosti na Hrvaškem: analiza volilnih kampanj na parlamentarnih volitvah 2003 in 2007 [Personality politics in Croatia: An inquiry into election campaigns in parliamentary elections in 2003 and 2007]. Teorija in praksa, 45(6), 788-816.

Grbeša, M. (2010). Privatisation of politics in Croatia: Analysis of the 2003 and 2007 Parliamentary Elections. Medijska istraživanja, 16(2), $57-78$.

Grbeša, M. (2012). Framing of the President: Newspaper coverage of Milan Bandić and Ivo Josipović in the Presidential Elections in Croatia in 2010. Politička misao, 49(5), 89-113.

Happer, C., \& Philo, G. (2013). The role of the media in the construction of public belief and social change. Journal of Social and Political Psychology, 1(1), 321-336. https://doi.org/10.5964/jspp.v1i1.96

Holtz-Bacha, C., Langer, A. I., \& Merkle, S. (2014). The personalisation of politics in comparative perspective: Campaign coverage in Germany and the United Kingdom. European Journal of Communication, 29(2), 153-170. https://doi.org/10.1177/0267323113516727

Hopmann, D. N., Vliegenthart, R., De Vreese, C., \& Albæk, E. (2010). Effects of election news coverage: How visibility and tone influence party choice. Political Communication, 27(4), 389-405. https://doi.org/ 10.1080/10584609.2010.516798

Hrt.hr (13 August 2016). HRT-ova debata Andreja Plenkovića i Zorana Milanovića najgledanija jučerašnja emisija na svim televizijama. Available at http://vijesti.hrt.hr/347721/hrt-ovu-televizijsku-debatu-andrejaplenkovica-i-zorana-milanovica-pratilo-vise-od-pola-milijuna-ljudi. 
DRUŠ. ISTRAŽ. ZAGREB GOD. 27 (2018), BR. 3, STR. 473-491

JUGO, D., CIBOCl, L., BANOVAC BARIĆ, $M$ : POLITICAL LEADERS..
Karvonen, L. (2010). The personalisation of politics. A Study of parliamentary democracies. Colchester: ECPR Press.

Kasapović, M. (2004). Personalizacija izbora: mit ili stvarnost? [Personalization of elections: Myth or reality?]. Društvena istraživanja, 13(3) 363-381.

Langer, A. I. (2011). The personalisation of politics in the UK: Mediated leadership from Attlee to Cameron. Manchester: Manchester University Press.

Malović, S. (2006). Osnove novinarstva [Basic journalism]. Zagreb: Golden marketing - Tehnička knjiga.

Media Act. Official Gazette, 59/2004, 84/2011, 81/2013.

Nimmo, D., \& Combs, J. E. (1983). Mediated political realities. New York: Longman.

Robinson, M. J. (1976). Public affairs television and the growth of political malaise: The case of "The Selling of the Pentagon". The American Political Science Review, 70, 409-432. https://doi.org/10.2307/1959647

Strömbäck, J. (2008). Four phases of mediatization: An analysis of the mediatization of politics. The International Journal of Press/Politics, 13(3), 228-246. https://doi.org/10.1177/1940161208319097

Swanson, D., \& Mancini, P. (Eds.) (1996). Politics, media and modern democracy. London: Praeger.

Šimunjak, M. (2012). Privatni život kao dio komunikacijske strategije hrvatskih političara: Predsjednički izbori 2009./2010. [The private life as part of Croatian politicians' communication strategies: The 2009-2010 Presidential Elections]. Medijske studije, 3(5), 34-50.

Šimunjak, M., Sinčić Ćorić, D., \& Brečić, R. (2017). Political impression management through direct and mediated communication: The 2014/2015 Croatian Presidential Elections. Društvena istraživanja, 26(4), 539-560. https://doi.org/10.5559/di.26.4.05

Van Aelst, P., Sheafer, T., \& Stanyer, J. (2012). The personalization of mediated political communication: A review of concepts, operationalizations and key findings. Journalism, 13(2), 203-220. https://doi.org/ 10.1177/1464884911427802

Vliegenthart, R., Boomgaarden, H. G., \& Boumans, J. W. (2011). Changes in political news coverage: Personalisation, conflict and negativity in British and Dutch newspapers. In K. Brants, \& K. Voltmer (Eds.), Challenging the primacy of politics (pp. 92-110). London: Palgrave.

Vučković, M. (2010). Leader-based voting in Croatia in a longitudinal perspective: 1990 - 2007. (Unpublished doctoral dissertation). Department of Political Science, Central European University, Budapest.

Vučković, M. (2016). Personalizacija politike u Hrvatskoj na prijevremenim parlamentarnim izborima 2016. godine [Personalisation of politics in the 2016 early parliamentary elections in Croatia]. Politicke analize, 27(9), 11-15.

Welsh, W. A. (1980). Survey research and public attitudes in Eastern Europe and the Soviet Union. Elmsford, N.Y: Pergamon Press. 
DRUŠ. ISTRAŽ. ZAGREB GOD. 27 (2018), BR. 3 STR. $473-491$

JUGO, D., CIBOCl, L., BANOVAC BARIĆ, $M$. POLITICAL LEADERS..

\section{Politički vođe u dnevnim novinama: analiza hrvatskih parlamentarnih izbora 2016.}

Damir JUGO, Lana CIBOCl, Maja BANOVAC BARIĆ

Edward Bernays Visoka škola za komunikacijski menadžment, Zagreb

Rad analizira izvještavanje dnevnih novina o ključnim političkim vođama parlamentarnih izbora u Hrvatskoj 2016. godine, prvih prijevremenih parlamentarnih izbora u Hrvatskoj koji su se dogodili kao posljedica raspada vladajuće koalicije. Uvod u ove nagle izbore na kojima se sustav preferencijalnoga glasovanja rabio tek drugi put bila je kratka izborna kampanja i promiena vođe najveće stranke (HDZ), što je utjecalo na snažnu prisutnost elementa personalizacije u kampanjama vodećih stranaka i koalicija. Ovaj rad analizira kako je pet vođa najjačih stranaka i koalicija bilo predstavljeno $u$ šest dnevnih novina za trajanja službene izborne kampanje. Rezultati istraživanja pokazali su kako su vođe dviju najvećih stranaka dominirali u medijskim objavama, ali i da je jedino novo lice među vođama u odnosu na prethodne izbore, predsjednik HDZ-a Andrej Plenković, imao izraženo pozitivan tretman $u$ većini analiziranih medija. Konačno, rezultati pokazuju i kako su se politički programi i privatan život političkih vođa pokazali kao marginalne teme medijskih objava posvećenih političkim vođama.

Ključne riječi: Hrvatska, parlamentarni izbori 2016., politički vođe, dnevne novine, personalizacija

\section{(c) (i) $(9)$}

Međunarodna licenca / International License:

Creative Commons Attribution-NonCommercial-NoDerivatives 4.0. 